\title{
Bezdroża w krainie edukacji, czyli wybrane doświadczenia doktoranta ze spektrum autyzmu w drodze do celu
}

\author{
Maciej Oksztulski \\ Uniwersytet w Białymstoku \\ maciekbial22@wp.pl \\ ORCID: https://orcid.org/0000-0002-7970-0231
}

\begin{abstract}
Wszyscy ludzie rodza się wolni i równi pod względem swej godności i swych praw.

Sa oni obdarzeni rozumem i sumieniem oraz powinni postępować $w$ stosunku do siebie wzajemnie $w$ duchu braterstwa.
\end{abstract}

Artykuł 1 Powszechnej Deklaracji Praw Człowieka ${ }^{1}$

\section{Wstęp}

Na wstępie należy postawić pytanie, czy Rzeczpospolita Polska zapewnia osobom ze spektrum autyzmu edukację na wszystkich szczeblach kształcenia, a dorosłym pomoc w uzyskaniu i utrzymaniu zatrudnienia.

Autyzm jest zaburzeniem neurorozwojowym, wpływającym całościowo na rozwój i funkcjonowanie danej osoby. Przyczyny autyzmu nie są w pełni znane - wpływ mają zarówno czynniki genetyczne, jak i środowiskowe. Przyczyną nie jest ani zaniedbanie ze strony rodziców, ani błędy wychowawcze ${ }^{2}$. Organizacja Na-

\footnotetext{
1 Zob. szerzej: Powszechna Deklaracja Praw Człowieka, uchwalona na III Sesji Ogólnego Zgromadzenia ONZ, Paryż, 10 grudnia 1948 r., http://www.unesco.pl/fileadmin [dostęp: 8.01.2020].

2 E. Bartnik, Czynniki biologiczne (genetyczne) wpływające na rozwój psychiczny i powstawanie zaburzeń, [w:] Psychiatria dzieci i młodzieży, red. J. Namysłowska, Warszawa 2004, s. 29-40.
} 
rodów Zjednoczonych (ONZ) uznała autyzm za jeden z najpoważniejszych problemów zdrowotnych świata obok raka, cukrzycy i AIDS (Acquired Immune Deficiency Syndrome) $)^{3}$. Obecnie wyróżnia się różnorodne formy kliniczne, które łącznie określa się jako całościowe zburzenie rozwojowe (12-C) lub zaburzenie ze spektrum autyzmu (ASD). Zaburzenia autystyczne występują we wszystkich grupach społecznych i różnych kulturach, jednak częściej u chłopców niż u dziewczynek (5:1). Diagnozę zespołu Aspergera stawia się zwykle trochę później niż diagnozę autyzmu - w wieku przedszkolnym, szkolnym, a nawet w dorosłości. W Polsce $\mathrm{w}$ procesie diagnozowania klinicyści wykorzystują Międzynarodową Klasyfikację Chorób i Zaburzeń Psychicznych ICD-10, zalecaną przez Światową Organizację Zdrowia (WHO). Zaburzenia ze spektrum autyzmu należą do zaburzeń psychicznych i mają oznaczenie $\mathrm{F} 84^{4}$.

Należy podkreślić, że nie istnieje lekarstwo na autyzm. Szanse na wyraźną poprawę stanu zdrowia są tym większe, im wcześniej postawi się diagnozę i zostanie podjęta intensywna terapia.

Do trzech kluczowych obszarów zaburzeń rozwojowych autyzmu lub zespołu Aspergera (ZA) należy zaliczyć:

1. Relacje społeczne - osoby te mają trudności z nawiązywaniem kontaktów i przestrzeganiem reguł społecznych oraz ze zrozumieniem reakcji i emocji innych ludzi. Często wyrażają własne uczucia w nietypowy sposób.

2. Komunikacja - osoby te mogą w ogóle nie mówić albo mieć ograniczony zasób słów; mogą też mówić płynnie, ale mieć trudności z wyrażaniem pojęć abstrakcyjnych. Nie potrafią kompensować tego gestem ani innymi formami przekazu.

3. Wyobraźnia - inaczej funkcjonująca wyobraźnia powoduje, że osoby te nie potrafią się bawić na niby, naśladować zachowania innych; przejawiają opór przed zmianami w otoczeniu przebiegu aktywności; mają dziwne zainteresowania i pasje.

Wiele osób z ASD wykazuje nadwrażliwość lub ograniczone reakcje na bodźce dotykowe, bólowe, słuchowe, wzrokowe i zapachowe ${ }^{5}$.

Badania pokazują, że autyzm nie jest to jeden zespół chorobowy, a grupa podobnych schorzeń. Według klasyfikacji Diagnostic and Statistical Manual of Mental Disorders (DSM-4) ${ }^{6}$ - klasyfikacji zaburzeń psychicznych Amerykańskiego Towa-

3 Zaburzenie autyzmu jako jedno z największych problemów zdrowotnych świata, http://www.mz.gov.pl [dostęp: 23.05.2020].

4 Załącznik nr 6 do zarządzenia nr 65/2007/DSOZ Prezesa NFZ z dnia 20 września 2007 r. w sprawie określania warunków zawierania umów.

$5 \quad$ Zob. szerzej: E. Pisula, Autyzm: od badań mózgu do praktyki psychologicznej, Sopot 2012, s. 15.

6 Inne, trudne, lecz nieobce. Informator Krajowego Towarzystwa Autyzmu, KTA Oddział w Łodzi, 2012. 
Bezdroża w krainie edukacji, czyli wybrane doświadczenia doktoranta...

rzystwa Psychiatrycznego - wyróżniamy następujące całościowe zaburzenia rozwoju: zaburzenia autystyczne, dziecięce zaburzenia dezintegracyjne, zaburzenie Retta, zaburzenie Aspergera (od nazwiska Hansa Aspergera) oraz głębokie zaburzenia rozwoju, nieujęte $\mathrm{w}$ innych kategoriach diagnostycznych. Niejednokrotnie z autyzmem mogą wystąpić inne czynniki, jak upośledzenie umysłowe oraz choroby: padaczka, alergie pokarmowe.

Autyzm diagnozuje się coraz częściej - w Polsce zaburzenia wykrywane są u 1 na 150 dzieci. Dane krajowe ciągle ulegają zmianie, ale szacuje się, że liczba osób chorych na autyzm wynosi kilkadziesiąt tysięcy. Brakuje danych co do liczby dzieci i dorosłych. Natomiast w Wielkiej Brytanii autyzm diagnozuje się u 1 na 100 dzieci $^{7}$. W Europie żyje z tą chorobą $5 \mathrm{mln}$ osób, czyli na 150 osób jedna dotknięta jest tym zaburzeniem. W USA występuje ono jeszcze częściej. Według Centers for Desease Control and Prevention (CDC) autyzm wykrywany jest w Stanach Zjednoczonych u 1 na 88 dzieci. Natomiast w latach 2008-2010 liczba diagnozowanych przypadków autyzmu u dzieci zwiększyła się aż o 30\%; obecnie diagnozuje się je u 1 na 68 dzieci (w tym 1 na 42 chłopców i 1 na 189 dziewczynek). Najnowsze dane w USA mówią o 1 przypadku na 54 urodzeń $^{8}$. Specjaliści nie wiedzą, czy taka zmiana to efekt gwałtownie rosnącej liczby przypadków zachorowań, doskonalszych metod diagnostycznych, czy też połączenie obu czynników. Natomiast psycholog Catherine Lord z Weill Cornell Medical College zauważa, że pomiędzy poszczególnymi stanami istnieje duża różnica w liczbie zdiagnozowanych przypadków (od 1 na 45 w New Jersey do 1 na 175 w Alabamie) ${ }^{9}$.

Obecnie około 50\% dzieci, u których zdiagnozowano ASD, wykazuje się przeciętną lub ponadprzeciętną inteligencją. Jeszcze 10 lat temu takie dzieci stanowiły ok. 30\% przypadków ASD. Tak duży wzrost prawdopodobnie jest spowodowany udoskonaleniem metod diagnostycznych. Zaburzenia ze spektrum autyzmu to niepełnosprawność niewidoczna - nieoczywista. Osoby dotknięte autyzmem lub zespołem Aspergera nie mają widocznych znamion niepełnosprawności; z uwagi na odmienność zachowania postrzegane są jako dziwaczne, niedostosowane. Zaburzenia ze spektrum autyzmu trwają przez całe życie i powodują poważną niepełnosprawnośćc ${ }^{10}$.

7 Zob. szerzej: E. Pisula, Autyzm u dzieci - diagnoza, klasyfikacja, etiologia, Warszawa 2000, s. 14.

8 Diagnoza autyzmu w USA (najnowsze dane), https://www.cdc.gov/ncbddd/autism/data.html [dostęp: 16.07.2020].

9 Zob. Diagnoza autyzmu, http://wiadomosci.wp.pl/kat,18032,title,Autyzm-jest-czestszy-niz-dawniej,wid,15457344, wiadomosc.html?ticaid=118564 [dostęp: 27.05.2020].

10 Szerzej: C.M. El Achkar, S.J. Spence, Clinical characteristics of children and young adults with co-occurring autism spectrum disorder and epilepsy, „Epilepsy \& Behavior” 2015, nr 47(14), s. 183-190; M. Sigman, S.J. Spence, A.T. Wang, Autism from developmental and neuropsychological perspectives, „Annual Review of Clinical Psychology" 2006, nr 2, s. 327-355. 
Spektrum autyzmu nie powoduje konieczności adaptacji architektonicznych, używania urządzeń i aparatury medycznej, a farmakologia ma w leczeniu osób $z$ autyzmem bardzo ograniczone zastosowanie. Podstawowym narzędziem jest drugi człowiek, pomagający w kontaktach ze środowiskiem. W terapii i rehabilitacji osób z autyzmem stosuje się rozmaite metody, w tym działania wspomagające rozwój mowy lub komunikacji alternatywnej, stymulację sensoryczną, trening umiejętności społecznej, integracji sensorycznej, wykorzystanie wizualnych środków przekazu w procesie edukacji i komunikacji ${ }^{11}$.

\section{Prawo do edukacji osób ze spektrum autyzmu w świetle standardów prawa międzynarodowego}

Osoby z autyzmem, ale też z zespołem Aspergera, są zależne od pomocy innych ze względu na ograniczone możliwości porozumiewania się, nawiązywania relacji społecznych, podejmowania decyzji dotyczących kierowania własnym życiem.

Prawo do nauki osób $\mathrm{z}$ autyzmem w świetle standardów międzynarodowych zostało zauważone w latach 90. XX w., mimo że dynamiczny rozwój praw człowieka w prawie międzynarodowym nastąpił po zakończeniu drugiej wojny światowej - głównie za sprawą działalności ONZ ${ }^{12}$. Uchwalenie Powszechnej Deklaracji Praw Człowieka (PDPC) było wydarzeniem o przełomowym znaczeniu. Jest ona aktem respektowanym przez większość państw świata. Artykuł 2 PDPC stanowi, że „każdy człowiek jest uprawniony do korzystania z wszystkich praw i wolności (...), bez względu na różnice rasy, koloru skóry, płci, języka religii, poglądów politycznych lub innych przekonań, narodowości, pochodzenia społecznego, majątku, urodzenia lub jakiekolwiek inne różnice". Artkuł 26 natomiast mówi o tym, że nauka powinna być bezpłatna i dostępna powszechnie na zasadzie równości dla każdego człowieka, a co za tym idzie - również dla osób autystycznych ${ }^{13}$.

Należy zwrócić uwagę na bardzo istotny akt prawny w prawie międzynarodowym, jakim jest Międzynarodowy pakt praw gospodarczych, społecznych i kulturalnych. O prawie do edukacji i zasadach jego realizacji traktują art. 13, 14 oraz 15. Zauważalny jest nacisk na fakt, że każdy, bez względu na jakiekolwiek czynniki zewnętrzne lub osobnicze, ma prawo do nauki i pełnego rozwoju osobowości. Nauka na poziomie podstawowym, określana i zapewniana przez państwo, powinna być nieodpłatna, powszechnie dostępna i obowiązkowa. Wykształcenie średnie powinno być udostępnione we wszystkich formach, w tym w ramach kształcenia techniczne-

11 Zob. szerzej: Zaburzenie autyzmu jako jedno z największych problemów zdrowotnych świata, http://www. mz.gov.pl [dostęp: 23.06.2020].

12 P.M. Bernitsas, Prawo do nauki, [w:] Prawa człowieka. Geneza, koncepcje, ochrona, red. B. Banaszak, Wrocław 1993, s. 36 i.

13 Powszechna Deklaracja..., art. 2 i 26. 
Bezdroża w krainie edukacji, czyli wybrane doświadczenia doktoranta...

go i zawodowego, natomiast studia wyższe, w zależności od zdolności, mają być dostępne dla każdego na zasadzie równości ${ }^{14}$. Jako że akt obejmuje zakresem każdego człowieka, nie ma potrzeby wyszczególniania w nim osób niepełnosprawnych. Realizacji zapewnionych przez pakt praw można dochodzić przed sądem krajowym, powołując się w skardze bezpośrednio na postanowienia paktu ${ }^{15}$, jednak ocena wywiązywania się z przyjętych przez państwo obowiązków uwzględniać powinna poziom rozwoju gospodarczego.

Kolejnym aktem międzynarodowym, na który należy zwrócić szczególną uwagę, jest Konwencja w sprawie likwidacji wszelkich form dyskryminacji kobiet z 1979 r. ${ }^{16}$ oraz Konwencja praw dziecka z 1989 r. ${ }^{17}$ Oba akty zostały przyjęte przez Zgromadzenie Ogólne ONZ w celu ochrony równego, pozbawionego dyskryminacji z jakiegokolwiek powodu dostępu do edukacji. Choć regulacje te nie odnoszą się bezpośrednio do osób ze spektrum autyzmu, to poprzez podkreślenie kwestii wyrównywania szans każdej kobiety i każdego dziecka obejmują swoim zakresem również osoby autystyczne.

Konwencja UNESCO odnosi się do problematyki zwalczania dyskryminacji w dziedzinie oświaty. UNESCO, jako wyspecjalizowana organizacja ONZ, stworzona została w celu działania na rzecz nauki i kultury oraz zacieśniania współpracy międzynarodowej w tych obszarach. Wskazuje ona jakie okoliczności kwalifikują się jako dyskryminacja i zobowiązuje państwa-strony do zwalczania wszelkich jej przejawów ${ }^{18}$. W Polsce działa Polski Komitet ds. UNESCO, odpowiedzialny za realizację programu „Edukacja dla Wszystkich”, którego celem jest eliminacja nierówności w dostępie do oświaty. Należy podkreślić, że komitet organizuje międzynarodowe konferencje, seminaria i warsztaty, a także koordynuje realizację projektów naukowych ${ }^{19}$.

Aktem międzynarodowym, którego nie sposób pominąć, jest Deklaracja praw osób z upośledzeniem umysłowym, odnosząca się bezpośrednio do osób ze spektrum autyzmu ze względu na sprzężenie tego schorzenia z dysfunkcjami umysłowymi. Przyjęta w 1971 r. przez ONZ delaracja ma na celu ochronę i pomoc osobom

14 Międzynarodowy pakt praw gospodarczych, społecznych i kulturalnych, http://prawo.sejm.gov.pl/isap.nsf/ DocDetails.xsp?id=WDU19770380169\&type=1 [dostęp: 13.07.2020].

15 B. Gronowska et al., Prawa człowieka i ich ochrona, Toruń 2010, s. 139.

16 Artykuł 10 Konwencji w sprawie likwidacji wszelkich form dyskryminacji kobiet z dnia 18 grudnia 1979 r. (Dz.U. z 1982 r. Nr 10, poz. 71), https://amnesty.org.pl/wp-content/uploads/2016/04/Konwencja-Likwidacja-dyskryminacji-kobiet.pdf [dostęp: 20.07.2020].

17 Konwencja praw dziecka, przyjęta przez Zgromadzenie Ogólne Narodów Zjednoczonych dnia 20 listopada 1989, art. 28 i 29 (Dz.U. z 1991 r. Nr 120, poz. 526), http://isap.sejm.gov.pl/isap.nsf/download.xsp/ WDU19911200526/O/D19910526.pdf [dostęp: 20.07.2020].

18 Konwencja UNESCO w sprawie zwalczania dyskryminacji w dziedzinie oświaty (Dz.U. z 1964 r. Nr 40, poz. 268), http://lipr.sejm.gov.pl/tek01/txt/onz/1960.html [dostęp: 17.07.2020].

19 S. Karowicz-Bienias, M. Oksztulski, Prawo do nauki osób z autyzmem. Wymiar międzynarodowy i krajowy, [w:] Prawo międzynarodowe. Teoria i Praktyka, red. I. Kraśnicka, Warszawa 2020, s. 283-284. 
dotkniętym upośledzeniami umysłowymi w osiągnięciu poziomu życia możliwie jak najbardziej zbliżonego do dostępnego dla osób zdrowych. Artykuł 2 zawiera uprawnienie osób niepełnosprawnych do otrzymania niezbędnej pomocy w celu maksymalnego potencjalnego rozwoju posiadanych zdolności ${ }^{20}$.

Mnogość regulacji dotyczących osób z niepełnosprawnościami zmusiła Zgromadzenie Ogólne ONZ do przyjęcia w 2006 r. Konwencji o prawach osób niepełnosprawnych $^{21}$ - to pierwszy w XXI w. akt o charakterze międzynarodowym, zawierający kompleksowe uregulowania tej materii. Należy zwrócić uwagę na art. 2 konwencji, który zawiera szereg definicji, a tym samym ujednolica nomenklaturę przedmiotu $^{22}$. Problem edukacji dzieci niepełnosprawnych ujęty został w art. 7, który nakłada na państwa-strony obowiązek podjęcia wszelkich niezbędnych środków w celu zapewnienia pełnego korzystania przez dzieci niepełnosprawne ze wszystkich praw i wolności przysługujących ich rówieśnikom. Ponadto w myśl art. 24 sektor publiczny powinien dołożyć wszelkich starań, by nauczanie miało charakter włączający oraz było prowadzone na wysokim poziomie, a przy tym pozostawało bezpłatne. Oznacza to, że szkoły publiczne (w tym szkoły wyższe) powinny zapewnić osobom $z$ niepełnosprawnościami dostęp do edukacji na zasadzie równości, indywidualne wsparcie oraz bezwarunkowo usprawnienia. Co więcej, artykuł ten omawia również konieczność zatrudniania i odpowiedniego kształcenia personelu pracującego na wszystkich szczeblach edukacji. W art. 23 natomiast podkreślana jest szczególna rola rodziców i opiekunów w trakcie całego procesu zdobywania wykształcenia ${ }^{23}$. Należy podkreślić, że konwencja z 2006 r. nie wprowadza nowych rozwiązań w zakresie ochrony praw człowieka. Standardy w niej zawarte ujęte zostały we wcześniejszych aktach prawa międzynarodowego. Stanowi ona jednak swego rodzaju unifikację dotychczasowych regulacji ${ }^{24}$.

20 Deklaracja praw osób z upośledzeniem umysłowym, http://www.niepelnosprawni.pl/ledge/x/7720 [dostęp: 17.07.2020].

21 Konwencja o prawach osób niepełnosprawnych, Nowy Jork, 13 grudnia 2006 r. Polska ratyfikowała konwencję dopiero w 2012 r. (Dz.U. z 2012 r. poz. 1169 ze sprost.), http://prawo.sejm.gov.pl/isap.nsf/download.xsp/ WDU20120001169/O/D20121169.pdf [dostęp: 17.07.2020].

22 S. Karowicz-Bienias, M. Oksztulski, Prawo do nauki..., s. 284.

23 Konwencja o prawach..., art. 7, 23 i 24.

24 Nową instytucją powołaną przez Konwencję o prawach osób niepełnosprawnych jest Konwencja ds. praw osób niepełnosprawnych, do której można składać petycje w przypadku naruszenia postanowień konwencji po wyczerpaniu krajowej ścieżki legislacyjnej. 
Bezdroża w krainie edukacji, czyli wybrane doświadczenia doktoranta...

\section{Prawo do edukacji osób ze spektrum autyzmu w świetle standardów prawa Unii Europejskiej}

W Europie kluczową rolę w prawie do nauki zajmuje Unia Europejska, która opracowała unikatowy system prawny, nacechowany prymatem prawa krajowego oraz bezpośredniością stosowania i skutku ${ }^{25}$. Prawo do edukacji osób ze spektrum autyzmu w prawie Unii Europejskiej kształtowało się przez wiele lat i proces ten wciąż trwa.

W prawie Unii Europejskiej należy wskazać dyrektywę Rady 2000/78 WE z dnia 27 listopada 2000 r., która ustanawia ogólne warunki ramowe równego traktowania $\mathrm{w}$ zakresie zatrudnienia i pracy ${ }^{26}$. Warto tu zwrócić uwagę na wyrok Trybunału z dnia 11 listopada 2006 r. w sprawie Sonia Chacón Navas przeciwko Eurest Colectividds $\mathrm{SA}^{27}$, definiujący niepełnosprawność jako ograniczenie, wynikające konkretnie $z$ naruszenia funkcji fizycznych, umysłowych lub psychicznych, które stanowi przeszkodę dla danej osoby w uczestnictwie w życiu zawodowym. Trybunał podkreślił również, że aby ograniczenie wchodziło w zakres pojęcia niepełnosprawności, musi istnieć prawdopodobieństwo, iż jest ono długoterminowe. W rezultacie osoba, z którą pracodawca rozwiązuje umowę o pracę wyłącznie z powodu choroby, nie jest objęta ogólnymi ramami ustanowionymi przez dyrektywę 2000/78/WE w celu walki z dyskryminacją ze względu na niepełnosprawność. Istotny dla identyfikacji statusu prawnego autystów w Unii Europejskiej jest art. 5 wyżej wymienionej dyrektywy, stanowiący o racjonalnych uprawnieniach dla osób niepełnosprawnych.

Należy także wskazać, że Karta praw podstawowych w art. 21 dotyczącym bezpośrednio osób niepełnosprawnych zakazuje wszelkiego rodzaju dyskryminacji ${ }^{28}$. Natomiast jej art. 26 stanowi, że „Unia uznaje i szanuje prawo osób niepełnospraw-

25 Zob. „Zasada bezpośredniego skutku prawa umożliwia podmiotom indywidualnym powoływanie się bezpośrednio na prawo wspólnotowe przed europejskimi sądami. Zasada ta jednak odnosi się tylko do niektórych aktów prawnych, a powołanie się na nią możliwe jest po spełnieniu kilku warunków". Natomiast dyrektywa jest aktem adresowanym do krajów UE i musi zostać przez nie poddana transpozycji do prawa krajowego. Jednak Trybunał Sprawiedliwości uznaje, że w niektórych przypadkach ma zastosowanie zasada bezpośredniego skutku w celu ochrony praw osób indywidualnych, https://eur-lex.europa.eu/legal-content/PL/TXT/ HTML/?uri=LEGISSUM:I14547\&from=PL [dostęp: 8.02.2020].

26 Dyrektywa 2000/78/WE Parlamentu Europejskiego i Rady z dnia 27 listopada 2000 r. ustanawiająca ogólne warunki ramowe równego traktowania w zakresie zatrudnienia i pracy (Dz.Urz. UE L 303).

27 Orzeczenie dotyczące dyrektywy 2000/78/WE. Równość traktowania w dziedzinie zatrudnienia i pracy. Pojęcie niepełnosprawności, http://www.prawo.pl/akty/dz-u-ue-c-2006-224-9-1,67633179.html [dostęp: 14.07.2020].

28 Karta praw podstawowych Unii Europehjskiej w art. 21 stanowi: „W celu zagwarantowania przestrzegania zasady równego traktowania osób niepełnosprawnych, przewiduje się wprowadzenie racjonalnych usprawnień to, jest że pracodawca podejmuje właściwe środki z uwzględnieniem potrzeb konkretnej sytuacji, aby umożliwić osobie niepełnosprawnej dostęp do pracy, wykonywanie jej lub rozwój zawodowy, bądź kształcenie, o ile środki te nie nakładają na pracodawcę nieproporcjonalnie wysokich obciążeń. Obciążenia te nie są nieproporcjonalne, jeżeli są w wystarczającym stopniu rekompensowane ze środków istniejących w ramach polityki prowadzonej przez dane Państwo Członkowskie na rzecz osób niepełnosprawnych", https://eur-lex.europa.eu/ legal-content/pl/TXT/?uri=CELEX\%3A12012P\%2FTXT [dostęp: 5.07.2020]. 
nych do korzystania ze środków mających zapewnić samodzielność, integrację społeczną i zawodową oraz udział w życiu społeczności”.

Zapewnienie edukacji leży w kompetencjach państw członkowskich. Sprawę kształcenia zawodowego regulowała w pierwszej kolejności decyzja Rady 63/226/ EWG z dnia 2 kwietnia 1963 r., dotycząca przyjęcia ogólnych zasad realizacji wspólnej polityki w dziedzinie kształcenia zawodowego ${ }^{29}$. W zakresie współpracy między państwami członkowskimi należy wskazać na program zmierzający do utworzenia Europejskiego Obszaru Szkolnictwa Wyższego, związany z tzw. procesem bolońskim, uruchomiony deklaracją ministrów edukacji państw europejskich z 1990 r., zmierzający do zwiększenia mobilności studentów, wypracowania jednolitej kompleksowej strategii kształcenia i szkolenia, zwany Kształcenie i szkolenie 2010 oraz poprawienia słabo zinstytucjonalizowanej Strategii lizbońskiej ${ }^{30}$. 6 grudnia $1994 \mathrm{r}$. ustanowiono program działań realizujący politykę Wspólnoty Europejskiej w zakresie kształcenia zawodowego ${ }^{31}$. Statut szkół europejskich, którego dyplomy i świadectwa są uznawane na terytorium państw członkowskich, zawarty został w konwencji z $1994 \mathrm{r}^{32}$

Należy podkreślić, że Parlament Europejski w 1996 r. zatwierdził Kartę praw osób z autyzmem ${ }^{33}$, która wpłynęła na ustanowienie równorzędnych praw osób $\mathrm{z}$ autyzmem $\mathrm{w}$ niektórych krajach, przyczyniając się do istotnie lepszego zrozumienia trudności, jakich doświadczają w życiu codziennym osoby ze spektrum autyzmu. W art. 3 tego dokumentu zawarte zostało prawo do powszechnej i odpowiedniej edukacji. Głównym celem edukacji osób ze spektrum autyzmu jest umożliwienie im właściwego przystosowania się do środowiska i rozwoju w kontakcie ze społeczeństwem ${ }^{34}$.

Mobilność na obszarze Wspólnoty dla studentów oraz osób przechodzących szkolenia, wolontariuszy, nauczycieli i trenerów ujęta została w zaleceniu Parlamentu Europejskiego i Rady z dnia 10 lipca 2001 - 2001/613/WE ${ }^{35}$. Istotnym ak-

29 Decyzja Rady 63/226/EWG z dnia 2 kwietnia 1963 roku ustanawiająca ogólne zasady wdrażania wspólnej polityki szkoleń zawodowych (Dz.Urz. UE L 63, s. 1338).

30 J. Pawlikowski, Wpływ procesu bolońskiego na rozwój polskich szkół wyższych, [w:] Rada Europy a przemiany demokratyczne w państwach Europy Środkowej i Wschodniej w latach 1989-2009, red. J. Jaskiernia, Toruń 2010, s. 640-643.

31 Decyzja Rady 94/819/EC z dnia 6 grudnia 1994 r. ustanawiająca program działań na rzecz wdrożenia polityki Wspólnoty Europejskiej w zakresie szkolenia zawodowego (Dz.Urz. UE L 340, s. 8).

32 Konwencja określająca statut szkół europejskich, których dyplomy i świadectwa są uznawane na terytorium Państw Członkowskich z 1994 r. (Dz.Urz. UE L 213, s. 3).

33 Karta praw osób z autyzmem, zatwierdzona przez Parlament Europejski w 1996 r., http://www.centrumautyzu. $\mathrm{pl} /$ autyzm/karta-praw-osób-z-autyzmem.html [dostęp: 4.01.2020].

34 Zob. P. Matthews, T. Matthews, Karta praw osób z autyzmem, refleksje i osobiste doświadczenia, Warszawa 2013.

35 Zalecenie 2001/613/WE Parlamentu Europejskiego i Rady z dnia 10 lipca 2001 r. w sprawie mobilności uczniów i studentów, osób odbywających szkolenia, młodych wolontariuszy, nauczycieli i instruktorów (Dz.Urz. UE L 215, s. 30). 
Bezdroża w krainie edukacji, czyli wybrane doświadczenia doktoranta...

tem prawnym była dyrektywa Rady 2004/114/WE z dnia 13 grudnia 2004 r., w której ustalono m.in., że „obywatel państwa trzeciego składający wniosek o przyjęcie na studia w państwie członkowskim, musi przedstawić żądane przez państwo członkowskie dowody wskazujące, że w czasie swojego pobytu będzie posiadał wystarczające środki na pokrycie kosztów utrzymania i podróży powrotnej" ${ }^{36}$. Ważną częścią działania Unii Europejskiej są programy długofalowe, jak np. decyzja Parlamentu Europejskiego i Rady 1719/2006/WE z dnia 15 listopada 2006 r. ustanawiająca program Młodzież w działaniu na okres 2007-2013 ${ }^{37}$. Należy podkreślić, że decyzją 1720/2006/WE z 15 listopada 2006 r. Parlament Europejski i Rada ustanowiły program działań w zakresie uczenia się przez całe życie, który jest kontynuacją wcześniejszych programów: Socrates, Leonardo da Vinci oraz E-learning Programme. W skład tego programu wchodzi program Comenius, dotyczący potrzeb dydaktycznych na poziomie przedszkolnym i szkolnym, oraz Erasmus, adresowany do osób korzystających ze studiów wyższych, a także Grundtvig, skierowany do osób korzystających $\mathrm{z}$ form kształcenia dorosłych ${ }^{38}$.

Dopiero traktat z Lizbony usystematyzował prawo do nauki w Traktacie o Funkcjonowaniu Unii Europejskiej (TFUE) w art. 165 ust. 1 stwierdzono, że „UE przyczynia się do rozwoju edukacji o wysokiej jakości poprzez zachęcanie do współpracy między państwami członkowskimi oraz, jeśli to niezbędne, przez wspieranie i uzupełnianie ich działalności, w pełni szanując odpowiedzialność tych państw za treść nauczania i organizację systemów edukacyjnych, jak również ich różnorodność kulturową i językową" ${ }^{39}$. W ust. 2 art. 165 TFUE wskazano, że działania Unii zmierzają do rozwoju wymiaru europejskiego edukacji przez nauczanie i rozpowszechnianie języków państw członkowskich, sprzyjanie mobilności studentów i nauczycieli czy też pobieranie rozwoju kształcenia na odległość ${ }^{40}$.

Karta praw podstawowych Unii Europejskiej jest efektem działań Unii na rzecz promowania i ochrony praw człowieka. Karta łączy w sobie prawa obywatelskie, polityczne, socjalne, ekonomiczne i kulturalne. Postanowień karty muszą przestrzegać zarówno instytucje i organy Unii Europejskiej, jak i państwa członkowskie w ramach stosowania prawa unijnego. Nadal jednak korzystanie z karty stanowi wyzwanie dla sędziów, prawników, przedstawicieli organizacji społecznych oraz zainteresowanych osób.

36 Dyrektywa Rady 2004/114/WE z dnia 13 grudnia 2004 r. w sprawie warunków przyjmowania obywateli państw trzecich w celu odbywania studiów, udziału w wymianie młodzieży szkolnej, szkoleniu bez wynagrodzenia lub wolontariacie (Dz.Urz. UE L 375/12).

Decyzja nr 1719/2006/WE Parlamentu Europejskiego i Rady z dnia 15 listopada 2006 r. ustanawiająca program Młodzież w działaniu na okres 2007-2013 (Dz.Urz. UE L 327, s. 30).

38 Decyzja nr 1720/2006/WE Parlamentu Europejskiego i Rady ustanawiająca z dnia 15 listopada 2006 r. program dzałań w zakresie uczenia się przez całe życie (Dz.Urz. UE L 327, s. 40).

39 Traktat o funkcjonowaniu Unii Europejskiej, art. 165 (Dz.Urz. UE C 326, s. 47).

40 Ibidem. 
Gdy traktat z Lizbony wszedł w życie 1 grudnia 2009 r., Karta praw podstawowych Unii Europejskiej stała się dokumentem prawnie wiążącym, na równi z traktatami, dla instytucji unijnych i krajów członkowskich w zakresie, w jakim stosują one prawo Unii ${ }^{41}$.

Głównym celem karty, zgodnie z preambułą KPP, jest wyraźne uznanie i podkreślenie roli praw podstawowych. W dokumencie tym zebrano prawa podstawowe chronione przez Unię Europejską i sprecyzowano obszary ochrony. Ponadto celem karty jest zapewnienie przestrzegania jej postanowień przez instytucje Unii i państwa członkowskie ${ }^{42}$. Do praw podstawowych należy zaliczyć prawo do nauki, które zawarte zostało w art. 14 KPP. Prawo to wywodzi się z art. 2 Protokołu dodatkowego do $\mathrm{EKPC}^{43}$. W stosunku do standardu wyboru zawodu konwencyjnego zakres został poszerzony o prawo do kształcenia dla uzyskania zawodu oraz dokształcania zgodnie z postanowieniami art. 15 KPP: Wolność wyboru zawodu i prawo do podejmowania pracy ${ }^{44}$. Natomiast w art. 14 ust. 2 wskazano, że „Prawo to obejmuje możliwość korzystania z bezpłatnej nauki obowiązkowej”, co oznacza, że każde dziecko ma prawo do bezpłatnych instytucji naukowych ${ }^{45}$.

Kartę powinny stosować instytucje i organy Unii Europejskiej. Jej postanowień powinny przestrzegać również wszystkie państwa członkowskie, zwłaszcza gdy działają w ramach prawa Unii. Obowiązek stosowania KPP przez państwa członkowskie jest wciąż przedmiotem dyskusji, ale zakłada się, że gdy stosują one prawo $\mathrm{UE}$, to są zobowiązane także do przestrzegania praw zawartych w karcie ${ }^{46}$. Ostatnio wiele się pisze na tematy dotyczące praworządności w UE, jak i poszczególnych państwach członkowskich ${ }^{47}$. Należy podkreślić, że choć prawo do nauki jest zagadnieniem ważnym, to jednak nie priorytetowym. Komisja Europejska jako strażniczka traktatów ma do odegrania szczególną rolę. Niemniej jednak wszystkie instytu-

41 Wersje skonsolidowane Traktatu o Unii Europejskiej i Traktatu o funkcjonowaniu Unii Europejskiej (Dz.Urz. UE C 326/47).

42 Karta praw podstawowych..., preambuła.

43 Protokół nr 1 do Konwencji o ochronie praw człowieka i podstawowych wolności (Dz.U. z 1995 r. Nr 36 , poz. 175).

44 Ibidem, art. 15.

45 C. Mik, Karta Praw Podstawowych. Znaczenie dla umocnienia jednostki w UE, [w:] Ochrona praw podstawowych w Unii Europejskiej, red. J. Barcz, Warszawa 2008, s. 124.

46 E. Bojarski et al., Karta Praw Podstawowych Unii Europejskiej jako żywy instrument, Warszawa 2014, s. 16.

473 kwietnia 2019 r. Komisja Europejska opublikowała komunikat Dalsze umacnianie praworządności w Unii, w którym określono trzy filary przyszłych działań: promocję, zapobieganie i reagowanie. W odpowiedzi na komunikat Komisja otrzymała ponad 60 opinii od wielu różnych podmiotów, w tym państw członkowskich, instytucji i organów UE, organizacji międzynarodowych i podmiotów politycznych, sieci sądowych i sądowych, organizacji społeczeństwa obywatelskiego, środowisk akademickich i stowarzyszeń biznesowych. Przegląd sugestii zawartych w komentarzach można znaleźć w raporcie podsumowującym za rok 2019, https://ec.europa.eu/info/policies/justice-and-fundamental-rights/upholding-rule-law/rule-law/initiative-strengthen-rule-laweu_en\#documents [dostęp: 12.07.2020]. 
Bezdroża w krainie edukacji, czyli wybrane doświadczenia doktoranta...

cje Unii i państwa członkowskie są odpowiedzialne za zapewnienie przestrzegania praworządności jako podstawowej wartości Unii.

Na Kartę praw podstawowych można powołać się bezpośrednio przed organami i instytucjami UE, np. w postępowaniu prowadzonym przez Komisję Europejską lub Europejskiego Rzecznika Praw Obywatelskich (ERPO). Na KPP można powołać się także przed organami krajowymi, gdy stosują one prawo Unii, w tym w postępowaniu przed krajowym sądem, który może zastosować kartę bezpośrednio lub skierować (w trybie art. 267 Traktatu o funkcjonowaniu Unii Europejskiej) pytanie prejudycjalne do Trybunału Sprawiedliwości Unii Europejskiej ${ }^{48}$.

Kolejnym istotnym aktem prawnym była Konwencja o prawach osób niepełnosprawnych z 2006 r., która została przyjęta przez Unię Europejską w styczniu 2011 r. Konwencja ma stworzyć warunki do tego, aby osoby niepełnosprawne korzystały z przysługujących im praw na równi ze wszystkimi innymi obywatelami. Jest to pierwszy taki kompleksowy traktat odnoszący się do prouszanego problemu, który został ratyfikowany przez Unię Europejską jako całość ${ }^{49}$.

\section{Prawo do edukacji osób ze spektrum autyzmu w świetle standardów prawa Rzeczypospolitej Polskiej}

Interpretacja powszechnego i równego dostępu do nauki może być różna. Każdy obywatel państwa ma prawo do nauki, każdy może się kształcić i nic ani nikt nie może mu w tym przeszkodzić. Państwo ma obowiązek zapewnić obywatelski dostęp do edukacji. Każdy obywatel jest równouprawniony w dostępie do nauki. Nie ma tu znaczenia status społeczny, pochodzenie, płeć, wygląd czy majętność. Zakres wertykalny jest na tyle otwarty, że każdy może zostać nawet uczonym, jeżeli ma do tego predyspozycje, a państwo powinno mu to umożliwić. Z drugiej strony każdy obywatel jest obowiązany kształcić się do 18 . roku życia ${ }^{50}$.

Należy pamiętać o art. 32 ust. 1 Konstytucji, który stanowi o równości wszystkich obywateli wobec prawa, jak i art. 33, który gwarantuje każdej osobie znajdującej się pod jurysdykcją państwa polskiego równy dostęp do praw i wolności, a także zakazuje dyskryminacji z jakiejkolwiek przyczyny. Prawo do bezpłatnej nauki zagwarantowane zostało $\mathrm{w}$ art. $70 \mathrm{w}$ ramach praw socjalnych ${ }^{51}$. W doktrynie polskiej uprawnienie to ujmowane jest jednak najczęściej wśród praw kulturalnych

\footnotetext{
$48 \quad$ Ibidem.

49 Konwencja o prawach osób...

50 Zob. szerzej: P. Winczorek, Komentarz do Konstytucji Rzeczypospolitej z dnia 2 kwietnia 1997 r., Warszawa 2000, s. 92; P. Bała, Konstytucyjne prawo do nauki a polski system oświaty, Warszawa 2009, s. 221 i s. 228231; A. Łopatka, Jednostka. Jej prawa człowieka, Warszawa 2002, s. 231.

51 Cecha bezpłatności za naukę ma również swój walor ekonomiczny. Zob. M. Jabłoński, S. Jarosz-Żukowska, Prawo konstytucyjne w formie pytań i odpowiedzi, Wroclaw 2003, s. 227.
} 
jako umożliwiające odpowiedni rozwój intelektualnej jednostki ${ }^{52}$. Zgodnie z przywołanym artykułem prawo do nauki w Polsce w szkołach publicznych przysługuje każdemu nieodpłatnie ${ }^{53}$. Ponadto art. 70 zapewnia powszechny i równy dostęp do edukacji, a na państwo nałożono w tym celu obowiązek udzielania wielopłaszczyznowej pomocy indywidualnej, która powinna być świadczona bez względu na sytuację zdrowotną, rodzinną czy finansową ${ }^{54}$. Artykuł 73 natomiast gwarantuje wolność twórczości artystycznej, prowadzenia badań naukowych, ogłaszania ich wyników oraz nauczania, a także korzystania $\mathrm{z}$ dóbr kultury. W praktyce oznacza to, że każdy, w zależności od swoich predyspozycji, może korzystać z wykształcenia na poziomie wyższym ${ }^{55}$. Należy podkreślić, że zapewnienie tego prawa na gruncie konstytucyjnym jest niezwykle istotne ze względu na jego bezpośredni związek z podniesieniem statusu społecznego, kulturalnego oraz gospodarczego jednostki.

W grudniu 2016 r. została uchwalona ustawa - Prawo oświatowe, która normuje materię zawartą wcześniej w ustawie o systemie oświaty z $1991 \mathrm{r}$. W preambule Prawa oświatowego znalazło się wskazanie, że jego regulacje zostały ukształtowane z zasadami przedstawionymi w polskiej ustawie zasadniczej oraz traktatach międzynarodowych. Należy podkreślić, że w art. 1 wskazanego aktu podkreśla się konieczność zapewnienia każdemu obywatelowi, w tym osobom niepełnosprawnym, realizacji prawa do kształcenia, gwarancji możliwości nauki we wszystkich typach szkół oraz udostępnienie zindywidualizowanych form nauczania, dostosowanych do osobniczych potrzeb rozwojowych ${ }^{56}$. Trzeba pamiętać, że państwo podejmuje wiele inicjatyw związanych z powyższymi założeniami, do których należą m.in.: możliwość odroczenia obowiązku szkolnego do 9. roku życia, zapewnienie przez gminy bezpłatnego transportu do placówek w wieku przedszkolnym szkolnym czy też rewalidacyjno-wychowawczym do 25. roku życia. Tworzone są również szkoły specjalne, przeznaczone dla uczniów niepełnosprawnych umysłowo lub z niepełnosprawnościami sprzężonymi ${ }^{57}$. Ustawodawca nakłada obowiązek zamieszczenia w statucie placówek naukowych postanowień dotyczących organizowania opieki nad osobami niepełnosprawnymi ${ }^{58}$. Natomiast zajęcia rewalidacyjne dla nich przeznaczone umieścił w ramach podstawowych zadań dydaktyczno-wychowawczych

52 M. Jabłoński, S. Jarosz-Żukowska, Prawa Człowieka i systemy ich ochrony. Zarys wykładu, Wrocław 2004, s. 54.

53 P. Bała, Odpłatność studiów stacjonarnych w wyższej szkole publicznej w świetle art. 70 ust. 2 Konstytucji Rzeczypospolitej Polskiej, „Przegląd Prawa Publicznego” 2010, nr 5, s. 8-9. klopedyczny, red. W. Skrzydło, S. Grabowska, R. Grabowski, Warszawa 2009, s. 390.

55 M. Jabłoński, Wolność z art. 73 Konstytucji RP, [w:] Prawa i wolności obywatelskie w Konstytucji RP, red. B. Banaszak, Warszawa 2002, s. 562.

56 Ustawa z dnia 14 grudnia 2016 r. - Prawo oświatowe (tekst jedn. Dz.U. z 2020 r. poz. 910, 1378).

57 Ibidem.

$58 \quad$ Ibidem, art. 18 ust. 2, art. 38 ust. 1 oraz art. 39 ust. 4. 
Bezdroża w krainie edukacji, czyli wybrane doświadczenia doktoranta...

szkoły ${ }^{59}$. Artykuł 127 powyższej ustawy zawiera dokładne wytyczne dotyczące postępowania w stosunku do osób niepełnosprawnych w placówkach oświatowych ${ }^{60}$. Opisana ścieżka kształcenia specjalnego ma być realizowana w szkołach ogólnodostępnych z możliwością edukacji włączającej, szkołach integracyjnych lub z oddziałami integracyjnymi, a także w szkołach specjalnych. Kształcenie oraz wychowanie uczniów $\mathrm{z}$ niestandardowymi potrzebami ma być dostosowane do ich indywidualnych cech i służyć ma nie tylko umożliwieniu im pobierania nauki, ale także usprawnieniu zaburzeń, rewalidacji, resocjalizacji oraz otrzymania specjalistycznej opieki oraz pomocy. Warto podkreślić, że niepełnosprawni kandydaci mają pierwszeństwo w procesie rekrutacji do publicznych placówek oświatowych, w obszarze w których stale zamieszkują ${ }^{61}$.

Najnowszym aktem prawnym regulującym nauczanie na poziomie wyższym jest ustawa - Prawo o szkolnictwie wyższym i nauce, nazywana również „ustawą 2.0" lub Konstytucją dla Nauki. Zastąpiła ona aż cztery dotychczas obowiązujące w tej materii akty prawne, a mianowicie: prawo o szkolnictwie wyższym, ustawę o zasadach finansowania nauki, ustawę o stopniach i tytule naukowym, a także ustawę o kredytach i pożyczkach studenckich. Należy podkreślić, że ani w preambule, ani też w początkowych przepisach „ustawy 2.0” nie znajdziemy odniesień do osób z niepełnosprawnościami, nawet pośrednich odnoszących się do każdego człowieka. Dopiero art. 11 wskazuje, że jednym z podstawowych zadań jest zapewnienie osobom niepełnosprawnym odpowiednich warunków w procesie rekrutacyjnym do szkół wyższych, kształcenia oraz prowadzenia działalności naukowej, na co mają być przeznczone również środki pochodzące $z$ finansowania uczelni wyższych przez państwo ${ }^{62}$. Przewidziana jest pomoc finansowa w formie stypendiów dla osób niepełnosprawnych oraz stypendiów socjalnych, a osoby potrzebujące wsparcia materialnego mogą otrzymać je na preferencyjnych warunkach ${ }^{63}$. Należy podkreślić, że polski ustawodawca w „ustawie 2.0” kwestię wsparcia dla osób z niepełnosprawnościami potraktował bardzo lakonicznie oraz nie uwzględnił różnorodności rodzajów niepełnosprawności, którymi mogą być dotknięci kandydaci na studentów, osoby studiujące oraz doktoranci.

\footnotetext{
$59 \quad$ Ibidem, art. 109 ust. 1 pkt 3.

60 Ibidem, art. 127.

61 Ibidem, art. 131, art. 133-136, art. 142 oraz art. 145.

62 Ustawa z dnia 20 lipca 2018 r. - Prawo o szkolnictwie wyższym i nauce (tekst jedn. Dz.U. z 2020 r. poz. 85 z późn. zm.), art. 11 oraz 365 pkt 6.

63 Doktoranci ze stwierdzonym stopniem niepełnosprawności otrzymują stypendium doktoranckie zwiększone o $30 \%$ w stosunku do kwoty podstawowej. Zob. ibidem, art. 86-89, art. 93 oraz art. 209 ust. 7.
} 


\section{Wsparcie osób ze spektrum autyzmu w dorosłym życiu}

Chcąc pomóc osobom niepełnosprawnym w wyrównywaniu szans na bycie pełnoprawnymi członkami społeczności, należy pamiętać o likwidowaniu barier prawnych, społecznych, architektonicznych, komunikacyjnych. Bariery te w szczególny sposób ograniczają osobom niepełnosprawnym równe szanse $\mathrm{w}$ realizacji prawa do pracy.

Nie sposób pominąć art. 67 ust. 1 Konstytucji, który stanowi: „Obywatel ma prawo do zabezpieczenia społecznego w razie niezdolności do pracy ze względu na chorobę lub inwalidztwo oraz po osiągnięciu wieku emerytalnego”. Bardzo podobne brzmienie ma art. 69: „Osobom niepełnosprawnym władze publiczne udzielają, zgodnie z ustawą, pomocy w zabezpieczaniu egzystencji, przysposobieniu do pracy oraz komunikacji społecznej na mocy, którego zostało wydane szereg ustaw i te ustawy kształtują prawa obywateli polskich"64.

Dziś najbardziej pomocne w realizacji praw dorosłych osób ze spektrum autyzmu są: Kodeks pracy z 26 czerwca 1974 roku ${ }^{65}$, ustawa z dnia 13 czerwca 2003 r. o zatrudnieniu socjalnym ${ }^{66}$, a także ustawa z dnia 27 kwietnia z 2006 r. o spółdzielniach socjalnych ${ }^{67}$. Nie można zapomnieć także o ustawie z dnia 27 sierpnia 1997 r. o rehabilitacji zawodowej i społecznej oraz zatrudnieniu osób niepełnosprawnych $^{68}$, ustawie z 1987 r. o Rzeczniku Praw Obywatelskich (RPO) ${ }^{69}$, ustawie z 2000 r. o Rzeczniku Praw Dziecka (RPD) ${ }^{70}$ czy też ustawie z dnia 6 listopada 2008 r. o prawach pacjenta i Rzeczniku Praw Pacjenta ${ }^{71}$, które mogą pomóc w urzeczywistnieniu praw osób autystycznych. Do aktów prawnych, które służą pomocą osobom niepełnosprawnym, należy również zaliczyć ustawę z dnia 7 września 1991 r. o systemie oświaty ${ }^{72}$, którą zmieniła ustawa $z$ dnia 14 grudnia 2016 r. prawo oświatowe ${ }^{73}$, czy też ustawę z dnia 12 marca 2004 r. o pomocy społecznej ${ }^{74}$. W ślad za tymi ustawami winny iść rozporządzenia, które pomogą w urzeczywistnieniu Karty Praw Osób z Autyzmem. Należy zwracać uwagę na tę specyfikę we wszystkich przepisach regulujących system wsparcia osób autystycznych. Programy wsparcia dedykowane osobom niepełnosprawnym najczęściej wykluczają osoby autystyczne ze wzglądu

\footnotetext{
64 Konstytucja RP...

65 Ustawa z dnia 26 czerwca 1974 r. - Kodeks pracy (tekst jedn. Dz.U. z 2020 r. poz. 1320).

66 Ustawa z dnia 13 czerwca 2003 r. o zatrudnieniu socjalnym (tekst jedn. Dz.U. z 2020 r. poz. 176).

67 Ustawa z dnia 27 kwietnia 2006 r. o spółdzielniach socjalnych (tekst jedn. Dz.U. z 2020 r. poz. 2085).

68 Ibidem.

69 Ustawa z dnia 15 lipca 1987 r. o Rzeczniku Praw Obywatelskich (tekst jedn. Dz.U. z 2020 r. poz. 627).

70 Ustawa z dnia 6 stycznia 2000 r. o Rzeczniku Praw Dziecka (Dz.U. z 2000 r. Nr 6, poz. 69).

71 Ustawa z dnia 6 listopada 2008 r. o prawach pacjenta i Rzeczniku Praw Pacjenta (tekst jedn. Dz.U. z 2020 r. poz. 849).

72 Ustawa z dnia 7 września 1991 r. o systemie oświaty (tekst jedn. Dz.U. z 2020 r. poz. 1327).

73 Ustawa z dnia 14 grudnia 2016 r. - Prawo oświatowe (tekst jedn. Dz.U. z 2020 r. poz. 910, 1378).

74 Ustawa z dnia 12 marca 2004 r. o pomocy społecznej (tekst jedn. Dz.U. z 2020 r. poz. 1876.).
} 
Bezdroża w krainie edukacji, czyli wybrane doświadczenia doktoranta...

na ich specyficzne potrzeby i ograniczenia. Najczęściej bywa tak, że systemy pomocy społecznej, jak i rehabilitacji społeczno-zawodowej z reguły nie przyjmują osób z autyzmem. Dyskryminacja osób z autyzmem w Polsce jest podwójna, tj. w stosunku do osób pełnosprawnych, jak i do innych osób niepełnosprawnych.

Odzwierciedleniem realnego życia w dzisiejszych czasach osób ze spektrum autyzmu jest „raport NIK o wsparciu osób z autyzmem i zespołem Aspergera w przygotowaniu do samodzielnego funkcjonowania z 28 czerwca 2020 r. ${ }^{75}$, w którym stwierdza się, że obecnie brakuje wsparcia osób ze spektrum autyzmu w dorosłym życiu. Jak podkreślono, „opieka nad osobami z autyzmem lub zespołem Aspergera w okresie edukacji przebiegała poprawnie. Większości uczniów stworzono warunki do uzyskania wykształcenia i przygotowania zawodowego, z uwzględnieniem specyfiki ich niepełnosprawności”. Natomiast po zakończeniu edukacji osoby dorosłe ze spektrum autyzmu nie mają zagwarantowanej kontynuacji wsparcia i pełnego dostępu do skutecznej rehabilitacji, umożliwiającej przygotowanie do pracy i samodzielnego życia. W raporcie podkreślono również, że „może to oznaczać regres i utratę umiejętności, które osoby z autyzmem lub zespołem Aspergera nabywały prze wiele lat edukacji, a w konsekwencji prowadzić do wykluczenia społecznego"76.

Osoby ze spektrum autyzmu są zależne od pomocy innych ze względu na ograniczone możliwości porozumiewania się, nawiązywania relacji społecznych, poodejmowania decyzji dotyczących decydowania o własnym życiu. Jak stwierdziła Najwyższa Izba Kontroli (NIK), „Państwo jest zobowiązane do zapewnienia im edukacji na wszystkich szczeblach kształcenia, a dorosłym pomocy w uzyskaniu i utrzymaniu zatrudnienia"77. Po zakończeniu edukacji osoby z autyzmem moga podjąć zatrudnienie na tzw. otwartym rynku pracy. Powyższe badania (choć lakoniczne) pokazują, że przy odpowiednim wsparciu jest możliwe osiągnięcie przez osoby, u których nie wystąpiły deficyty intelektualne, znacznego poziomu samodzielności. Jednak wskaźnik zatrudnienia osób z tymi zaburzeniami w Polsce wynosi poniżej 1\%, podczas gdy w krajach Europy Zachodniej stanowi nawet kilkanaście procent ${ }^{78}$. Należy podkreślić, że sam fakt ukończenia nauki nie powoduje, że osoby ze spektrum autyzmu pozbywają się problemów wynikających z ich schorzeń. Jak zauważyła NIK, mogą one uczestniczyć w warsztatach terapii zajęcio-

75 Wsparcie osób z autyzmem i zespołem Aspergera w przygotowaniu do samodzielnego funkcjonowania, 28 czerwca 2020 r., https://www.nik.gov.pl/aktualnosci/wsparcie-osob-z-autyzmem-i-zespolem-aspergera.html [dostęp: 20.07.2020].

76 Ibidem; badaniem objęto woj. wielkopolskie, mazowieckie, podlaskie, łódzkie, świętokrzyskie oraz podkarpackie w latach 2016-2019 - jest to pierwsze badanie, mimo że nie obejmuje całego kraju, to zauważa problem dorosłych osób ze spektrum autyzmu w Polsce.

77 Ibidem; badanie polegało na sprawdzeniu, czy osobom z autyzmem i zespołem Aspergera zapewniono możliwość kształcenia zawodowego oraz przygotowania do prascy i samodzielnego życia. Ibidem. 
wej (WTZ), oferujących rehabilitację społeczną i zawodową, albo rozpocząć pracę na otwartym bądź chronionym rynku pracy, tj. w zakładzie pracy chronionej lub w zakładzie aktywności zawodowej (ZAZ). Jak ustalili kontrolerzy NIK, rehabilitacja społeczna i zawodowa prowadzona w ramach ZAZ i WTZ była tylko formalnie dostępna dla osób ze spektrum autyzmu. Świadczy o tym fakt, że tylko ok. 19\% ZAZ i w 22\% WTZ w województwach, w których realizowano kontrolę, wspierano osoby ze spektrum autyzmu ${ }^{79}$. Oznacza to, że w ogólnodostępnych placówkach WTZ i ZAZ osoby ze spektrum autyzmu praktycznie nie biorą udziału w procesie rehabilitacji.

Jednym z powodów, dla którego osoby z autyzmem i zespołem Aspergera tak nielicznie korzystały z zajęć w WTZ, był brak tam odpowiedniej kadry specjalistów $^{80}$. Kierownicy i specjaliści zatrudnieni w tych placówkach podkreślali, że zindywidualizowane podejście do osób z autyzmem wpłynie na lepsze rezultaty ich rehabilitacji społecznej i zawodowej. Do tego potrzebne jest jednak przeznaczenie większych środków na działalność WTZ i ZAZ, a także większa liczba tych placówek, w tym specjalistycznych - otwartych na potrzeby osób $\mathrm{z}$ autyzmem lub zespołem Aspergera. Żadna z placówek objętych kontrolą nie otrzymała od samorządu dodatkowych środków na wsparcie osób z autyzmem. Po zajęciach w WTZ osoby $\mathrm{z}$ autyzmem i zespołem Aspergera powinny być kierowane do pracy w zakładach aktywności zawodowej. Niestety, z powodu ich braku na terenie powiatów wybranych do kontroli nawet nieliczni uczestnicy WTZ, którzy uzyskiwali pozytywne wyniki rehabilitacji zawodowej, nie mogli jej kontynuować, pracując ${ }^{81}$.

Dla gorzej funkcjonujących osób organizuje się ośrodki wsparcia - środowiskowe domy samopomocy (ŚDS). Uczą one lub rozwijają umiejętności wykonywania codziennych czynności i funkcjonowania w życiu społecznym. Dostępność opieki dla osób z autyzmem poprawiła się w nich dzięki zwiększeniu o 30\% dotacji dla tych ośrodków ${ }^{82}$. Większość skontrolowanych ŚDS była właściwie zorgani-

79 Ibidem; należy zauważyć, że były to specjalistyczne placówki, przeznaczone tylko dla osób z autyzmem (jest ich zaledwie kilka na terenie Polski).

80 Ibidem; w WTZ nie zatrudniono psychologów, a inni specjaliści pracowali tylko na część etatu lub umowy zlecenie. To z kolei skutkowało brakiem zindywidualizowanego podejścia do osób ze spektrum autyzmu odpowiadającego specyfice tych zaburzeń, objawiającego się na przykład skłonnością do zachowań agresywnych czy deficytami uwagi. Dlatego prawie wszystkie osoby uczestniczące w terapii zajęciowej w WTZ (80\% osób objętych badaniem) nie osiągnęły założonych celów rehabilitacji zawodowej i społecznej.

81 Dane dotyczące zatrudnienia osób z autyzmem i z zespołem Aspergera w 2018 r. Na terenie wymienionych województw (podlaskie, mazowieckie, wielkopolskie, łódzkie, świętokrzyskie i podkarpackie), tj. w 9 ZAZ, zatrudnionych było łącznie 45 osób ze spektrum autyzmu.

82 W większości województw w latach 2016-2019 (I półrocze) wzrosła liczba osób z autyzmem objętych opieką w tych domach. W 2019 r. (I półrocze) w sześciu badanych województwach w porównaniu z końcem 2017 r. liczba osób z autyzmem w ŚDS wzrosła o 40\%. Dodatkowo w I połowie 2019 r. wprowadzono nowy ich typ dom typu $D$, specjalnie przeznaczony dla osób z autyzmem lub niepełnosprawnościami sprzężonymi, oraz wdrożono program mający na celu tworzenie centrów opiekuńczo-mieszkalnych, dobrze przygotowanych do takiej opieki. 
Bezdroża w krainie edukacji, czyli wybrane doświadczenia doktoranta...

zowana, we wszystkich prawidłowo sporządzano indywidulane plany postępowania wspierająco-aktywizującego i na bieżąco oceniano ich skuteczność. Jednak stan psychofizyczny uczestników domów powodował, że działania pracowników merytorycznych ukierunkowane były na ich rehabilitację społeczną, czyli rozwijanie umiejętności potrzebnych do samodzielnego funkcjonowania, a nie na rehabilitację mającą przygotować ich do pracy.

Po przeprowadzonej kontroli NIK skierowała wnioski do ministra rodziny pracy i polityki społecznej o:

- „przygotowanie zmian w prawie pozwalających na przeznaczenie dodatkowych środków na funkcjonowanie WTZ i ZAZ dla osób z autyzmem i zespołem Aspergera;

- stworzenie mechanizmu gromadzenia informacji na temat liczby osób z autyzmem lub zespołem Aspergera oraz charakteru ich potrzeb, $z$ uwzględnieniem danych gromadzonych w innych systemach orzeczniczych;

- wprowadzenie zachęt do utworzenia i funkcjonowania na terenie każdego powiatu trzech typów placówek wsparcia, tj. WTZ, ZAZ i ŚDS, co pozwoli na lepszą rehabilitację zawodową i społeczną oraz »drożność« systemu wsparcia”.

Do ministra nauki i szkolnictwa wyższego oraz prezesa GUS o:

- „ustalenie przez Ministra Nauki i Szkolnictwa Wyższego sposobu podziału środków finansowych dla uczelni, przeznaczonych na świadczenia dla studentów i stworzenie studentom niepełnosprawnym optymalnych warunków przyjmowania ich na studia i prowadzenia pracy naukowej, z uwzględnieniem grupy studentów i doktorantów z autyzmem i zespołem Aspergera;

- uwzględnienie przez Prezesa Głównego Urzędu Statystycznego w przygotowywanym na kolejne lata projekcie badań statystycznych możliwości uzyskiwania danych na temat osób z autyzmem lub zespołem Aspergera, które studiują lub pracują naukowo”.

Do jednostek prowadzących WTZ, ZAZ, ŚDS i dyrektorów szkół o:

- „tworzenie warunków do zwiększenia liczby specjalistów prowadzących kształcenie specjalne oraz rehabilitację zawodową i społeczną osób z autyzmem lub zespołem Aspergera;

- zagwarantowanie środków na sukcesywne eliminowanie barier architektonicznych w obiektach WTZ, ZAZ i ŚDS oraz dostosowanie infrastrukturalne tych placówek do rehabilitacji osób z autyzmem lub zespołem Aspergera; - prawidłowe ustalanie indywidualnych programów edukacyjno-terapeutycznych, indywidualnych programów rehabilitacji dla osób z au- 
tyzmem lub zespołem Aspergera, a także zakresu niezbędnej pomocy, wynikającej z rzeczywistej oceny funkcjonowania tych osób”33.

Bardzo istotną kwestią w realizowaniu powyższych postulatów jest przeprowadzenie badań ogólnokrajowych dotyczących osób ze spektrum autyzmu, które pomogą $\mathrm{w}$ przyszłości $\mathrm{w}$ pokonywaniu problemów związanych $\mathrm{z}$ egzystencją dorosłych osób autystycznych ${ }^{84}$. Chcąc zrealizować powyższe wnioski, które NIK skierowała do poszczególnych organów, należy na ten cel przeznaczyć odpowiednie środki finansowe, aby pomóc osobom ze spektrum autyzmu w uzyskaniu i utrzymaniu zatrudnienia, jak i zapewniania im godnego życia.

\section{Wnioski}

Na wstępie artykułu postawiono pytanie: czy Rzeczypospolita Polska zapewnia osobom ze spektrum autyzmu edukacji na wszystkich szczeblach kształcenia, a dorosłym pomoc w uzyskaniu i utrzymaniu zatrudnienia? Należy stwierdzić, że dla większości uczniów ze spektrum autyzmu stworzono warunki do uzyskania wykształcenia i przygotowania do zawodu oraz objęto specjalną opieką w systemie edukacji ${ }^{85}$. Natomiast po zakończeniu edukacji osoby dorosłe nie mają zagwarantowanej kontynuacji wsparcia i pełnego dostępu do skutecznej rehabilitacji, umożliwiającej przygotowanie ich do pracy i samodzielnego życia. Może to oznaczać regres i utratę umiejętności, które osoby z autyzmem lub zespołem Aspergera nabywały przez wiele lat edukacji, a w konsekwencji prowadzić do wykluczenia społecznego.

Dzieje się tak, ponieważ Karta Praw Osób z Autyzmem, jako uchwała sejmowa nieegzekwowana, nie skutkuje sankcjami prawnymi. Funkcją karty jest zwrócenie uwagi na specyficzne potrzeby osób autystycznych, różniących się zasadniczo od potrzeb osób z innymi niepełnosprawnościami. Należy podkreślić tę specyfikę we wszystkich przepisach regulujących system wsparcia osób autystycznych. Programy wsparcia skieorwane do osób niepełnosprawnych najczęściej wykluczają osoby autystyczne ze wzglądu na ich specyficzne potrzeby i ograniczenia. Wnioski ujęte $w$ raporcie NIK i skierowane do właściwych organów powinny przyczynić się do poprawy egzystencji dorosłych osób ze spektrum autyzmu, jednak wiąże się to z nakładami finansowymi, które nie zawsze da się wyegzekwować od organów zajmujących się sprawami osób z niepełnosprawnościami.

\footnotetext{
83 Wsparcie osób $z$ autyzmem ...

84 Do roku 2020 w Polsce nie próbowano policzyć osób ze spektrum autyzmu, próby dotyczyły dzieci i młodzieży - wyrywkowo w różnych województwach.

85 Przykładem jest autor, który jako osoba ze spektrum autyzmu (niemówiąca) jest doktorantem Wydziału Prawa na Uniwersytecie w Białymstoku i przed którym stoi problem podjęcia pracy.
} 
Bezdroża w krainie edukacji, czyli wybrane doświadczenia doktoranta...

Trzeba mieć nadzieję na lepsze jutro, bo autystów - niestety - przybywa, a byłoby paradoksem, gdyby rozwijający się coraz szybciej świat nie otwierał się na nich szerzej. Ze względu na specyficzny rodzaj schorzenia, jakim jest autyzm, należy podkreślić, że nie wyszczególniono tej choroby w przepisach prawnych dotyczących prawa do pracy. Osoba ze spektrum autyzmu odnajdzie się na rynku pracy wówczas, gdy stworzy się jej specyficzne warunki do pracy, które pomogą jej w miarę godnie funkcjonować w społeczeństwie. Koszty te będą znacznie niższe od kosztów leczenia, terapii, rehabilitacji i utrzymania w domu pomocy społecznej czy też w zakładzie leczniczym.

\section{Akty prawne}

Deklaracja praw osób z upośledzeniem umysłowym, http://www.niepelnosprawni.pl/ledge/x/7720.

Konwencja praw dziecka, przyjęta przez Zgromadzenie Ogólne Narodów Zjednoczonych dnia 20 listopada 1989, art. 28 i 29 (Dz.U. z 1991 r. Nr 120, poz. 526), http://isap. sejm.gov.pl/isap.nsf/download.xsp/WDU19911200526/O/D19910526.pdf.

Konwencja UNESCO w sprawie zwalczania dyskryminacji w dziedzinie oświaty (Dz.U. z 1964 r. Nr 40, poz. 268), http://lipr.sejm.gov.pl/tek01/txt/onz/1960.html.

Międzynarodowy pakt praw gospodarczych, społecznych i kulturalnych, http://prawo.sejm. gov.pl/isap.nsf/DocDetails.xsp?id=WDU19770380169\&type $=1$.

Powszechna Deklaracja Praw Człowieka, uchwalona na III Sesji Ogólnego Zgromadzenia ONZ, Paryż, 10 grudnia 1948 r., http://www.unesco.pl/fileadmin.

Decyzja Rady 63/226/EWG z dnia 2 kwietnia 1963 roku ustanawiająca ogólne zasady wdrażania wspólnej polityki szkoleń zawodowych (Dz.Urz. UE L 63).

Decyzja Rady 94/819/EC z dnia 6 grudnia 1994 r. ustanawiająca program działań na rzecz wdrożenia polityki Wspólnoty Europejskiej w zakresie szkolenia zawodowego (Dz.Urz. UE L 340).

Decyzja nr 1719/2006/WE Parlamentu Europejskiego i Rady z dnia 15 listopada 2006 r. ustanawiająca program Młodzież w działaniu na okres 2007-2013 (Dz.Urz. UE L 327).

Decyzja nr 1720/2006/WE Parlamentu Europejskiego i Rady z dnia 15 listopada 2006 r. ustanawiająca program dzałań w zakresie uczenia się przez całe życie (Dz.Urz. UE L 327).

Dyrektywa 2000/78/WE Parlamentu Europejskiego i Rady z dnia 27 listopada 2000 r. ustanawiająca ogólne warunki ramowe równego traktowania w zakresie zatrudnienia i pracy (Dz.Urz. UE L 303).

Dyrektywa Rady 2004/114/WE z dnia 13 grudnia 2004 r. w sprawie warunków przyjmowania obywateli państw trzecich w celu odbywania studiów, udziału w wymianie młodzieży szkolnej, szkoleniu bez wynagrodzenia lub wolontariacie (Dz.Urz. UE L 375/12). 
Europejska konwencja praw człowieka.

Karta praw osób z autyzmem, zatwierdzona przez Parlament Europejski w 1996 r., http:// www.centrumautyzu.pl/autyzm/karta-praw-osób-z-autyzmem.html.

Karta praw podstawowych Unii Europejskiej, https://eur-lex.europa.eu/legal-content/PL/ TXT/?uri=celex\%3A12012P\%2FTXT.

Konwencja o prawach osób niepełnosprawnych, Nowy Jork, 13 grudnia 2006 r. (Dz.U. z 2012 r. poz. 1169 ze sprost.).

Konwencja określająca statut szkół europejskich, których dyplomy i świadectwa są uznawane na terytorium Państw Członkowskich z 1994 r. (Dz.Urz. UE L 213).

Konwencja w sprawie likwidacji wszelkich form dyskryminacji kobiet $\mathrm{z}$ dnia 18 grudnia 1979 r. (Dz.U. z 1982 r. Nr 10, poz. 71), https://amnesty.org.pl/wp-content/uploads/2016/04/Konwencja-Likwidacja-dyskryminacji-kobiet.pdf.

Rozporządzenie Parlamentu Europejskiego i Rady (UE) 2016/679 z dnia 27 kwietnia 2016 r. w sprawie ochrony osób fizycznych w związku z przetwarzaniem danych osobowych i w sprawie swobodnego przepływu takich danych oraz uchylenia dyrektywy 95/46/WE (ogólne rozporządzenie o ochronie danych).

Traktat o funkcjonowaniu Unii Europejskiej (Dz.Urz. UE C 326, s. 47).

Wersje skonsolidowane Traktatu o Unii Europejskiej i Traktatu o funkcjonowaniu Unii Europejskiej (Dz.Urz. UE C 326/47).

Konstytucja Rzeczpospolitej Polskiej z dnia 2 kwietnia 1997 r. (Dz.U. z 1997 r. Nr 78, poz. 483).

Uchwała Sejmu Rzeczpospolitej Polskiej z dnia 12 lipca 2013 r. Karta praw osób z autyzmem (M.P. z 2013 r. poz. 682).

Ustawa z dnia 26 czerwca 1974 r. Kodeks pracy (tekst jedn. Dz.U. z 1998 r. Nr 21, poz. 94 z późn. zm.).

Ustawa z dnia 26 czerwca 1974 r. - Kodeks pracy (tekst jedn. Dz.U. z 2020 r. poz. 1320).

Ustawa z dnia 15 lipca 1987 r. o Rzeczniku Praw Obywatelskich (tekst jedn. Dz.U. z 2020 r. poz. 627).

Ustawa z dnia 7 września 1991 r. o systemie oświaty (tekst jedn. Dz.U. z 2020 r. poz. 1327).

Ustawa z dnia 6 stycznia 2000 r. o Rzeczniku Praw Dziecka (Dz.U. z 2000 r. Nr 6, poz. 69).

Ustawa z dnia 13 czerwca 2003 r. o zatrudnieniu socjalnym (tekst jedn. Dz.U. z 2020 r. poz. 176).

Ustawa z dnia 12 marca 2004 r. o pomocy społecznej (tekst jedn. Dz.U. z 2020 r. poz. 1876).

Ustawa z dnia 27 kwietnia 2006 r. o spółdzielniach socjalnych (tekst jedn. Dz.U. z 2020 r. poz. 2085).

Ustawa z dnia 6 listopada 2008 r. o prawach pacjenta i Rzeczniku Praw Pacjenta (tekst jedn. Dz.U. z 2020 r. poz. 849).

Ustawa z dnia 14 grudnia 2016 r. - Prawo oświatowe (tekst jedn. Dz.U. z 2020 r. poz. 910, 1378). 
Bezdroża w krainie edukacji, czyli wybrane doświadczenia doktoranta...

Ustawa z dnia 20 lipca 2018 r. - Prawo o szkolnictwie wyższym i nauce (tekst jedn. Dz.U. z 2020 r. poz. 85 z późn. zm.).

Protokół nr 1 do Konwencji o ochronie praw człowieka i podstawowych wolności (Dz.U. z 1995 r. Nr 36, poz. 175).

Zalecenie 2001/613/WE Parlamentu Europejskiego i Rady z dnia 10 lipca 2001 r. w sprawie mobilności uczniów i studentów, osób odbywających szkolenia, młodych wolontariuszy, nauczycieli i instruktorów (Dz.Urz. UE L 215).

Załącznik nr 6 do zarządzenia nr 65/2007/DSOZ Prezesa NFZ z dnia 20 września 2007 r. w sprawie określania warunków zawierania umów.

\section{Literatura}

Achkar C.M., Spence S.J., Clinical characteristics of children and young adults with co-occurring autism spectrum disorder and epilepsy, „Epilepsy \& Behavior” 2015, nr 47(14).

Bała P., Konstytucyjne prawo do nauki a polski system oświaty, Warszawa 2009.

Bała P., Odpłatność studiów stacjonarnych $w$ wyższej szkole publicznej w świetle art. 70 ust. 2 Konstytucji Rzeczypospolitej Polskiej, „Przegląd Prawa Publicznego” 2010, nr 5.

Bartnik E., Czynniki biologiczne (genetyczne) wpływające na rozwój psychiczny i powstawanie zaburzeń, [w:] Psychiatria dzieci i młodzieży, red. J. Namysłowska, Warszawa 2004.

Bernitsas P.M., Prawo do nauki, [w:] Prawa człowieka. Geneza, koncepcje, ochrona, red. B. Banaszak, Wrocław 1993.

Bojarski E. et al., Karta Praw Podstawowych Unii Europejskiej jako żywy instrument, Warszawa 2014.

Diagnoza autyzmu, http://wiadomosci.wp.pl/kat,18032,title,Autyzm-jest-czestszy-niz-dawniej,wid,15457344, wiadomosc.html?ticaid=118564.

Diagnoza autyzmu w USA (najnowsze dane), https://www.cdc.gov/ncbddd/autism/data.html.

Gronowska B. et al., Prawa człowieka i ich ochrona, Toruń 2010.

Inne, trudne, lecz nieobce. Informator Krajowego Towarzystwa Autyzmu, KTA Oddział w Łodzi, 2012.

Jabłoński M., Wolność z art. 73 Konstytucji RP, [w:] Prawa i wolności obywatelskie w Konstytucji RP, red. B. Banaszak, Warszawa 2002.

Jabłoński M., Jarosz-Żukowska S., Prawo konstytucyjne w formie pytań i odpowiedzi, Wroclaw 2003.

Jabłoński M., Jarosz-Żukowska S., Prawa Człowieka i systemy ich ochrony. Zarys wykładu, Wrocław 2004.

Karkowska D., Ustawa o prawach pacjenta i Rzecznika Praw Pacjenta. Komentarz, wyd. 2, Warszawa 2012. 
Karowicz-Bienias S., Oksztulski M., Prawo do nauki osób z autyzmem. Wymiar międzynarodowy i krajowy, [w:] Prawo międzynarodowe. Teoria i praktyka, red. I. Kraśnicka, Warszawa 2020.

Łopatka A., Jednostka. Jej prawa człowieka, Warszawa 2002.

Matthews P., Matthews T., Karta praw osób z autyzmem, refleksje i osobiste doświadczenia, Warszawa 2013.

Michałowska K., Charakter prawny i znaczenie zgody pacjenta na zabieg medyczny, Warszawa 2014.

Mik C., Karta Praw Podstawowych. Znaczenie dla umocnienia jednostki w UE, [w:] Ochrona praw podstawowych w Unii Europejskiej, red. J. Barcz, Warszawa 2008.

Pawlikowski J., Wpływ procesu bolońskiego na rozwój polskich szkół wyższych, [w:] Rada Europy a przemiany demokratyczne w państwach Europy Środkowej $i$ Wschodniej w latach 1989-2009, red. J. Jaskiernia, Torun 2010.

Pisula E., Autyzm u dzieci - diagnoza, klasyfikacja, etiologia, Warszawa 2000.

Pisula E., Autyzm: od badań mózgu do praktyki psychologicznej, Sopot 2012.

Sigman M., Spence S.J., Wang A.T., Autism from developmental and neuropsychological perspectives, „Annual Review of Clinical Psychology” 2006, nr 2.

Winczorek P., Komentarz do Konstytucji Rzeczypospolitej z dnia 2 kwietnia 1997 r., Warszawa 2000.

Wsparcie osób z autyzmem i zespołem Aspergera w przygotowaniu do samodzielnego funkcjonowania, 28 czerwca 2020 r., https://www.nik.gov.pl/aktualnosci/wsparcie-osob-z-autyzmem-i-zespolem-aspergera.html.

Zaburzenie autyzmu jako jedno $z$ największych problemów zdrowotnych świata, http://www. mz.gov.pl.

Zięba-Załucka H., hasło: prawo do nauki, [w:] Konstytucja Rzeczypospolitej Polskiej. Komentarz encyklopedyczny, red. W. Skrzydło, S. Grabowska, R. Grabowski, Warszawa 2009. 